\title{
The Implementation Of Character Education Values In Integrated Physical Education Subject In Elementary School
}

\author{
Ayi Suherman ${ }^{1 *}$ \\ Program Studi PSD Penjas, Universitas Pendidikan Indonesia Kampus Sumedang, Jl. Mayor \\ Abdurachman No. 211 Sumedang, Jawa Barat, Indonesia
}

\begin{abstract}
The issue of this research emphasizes on the implementation of character building values through physical education learning in elementary school. The effort in developing this character building practice is essential to be done in order to tackle moral and character crises, which already occur in both individual and collective levels reflected in educational institution from elementary school to higher education. Hence, to form culture and national character, educational program and process are inseparable from environmental factor including the values of society, culture, and humanity. Physical education subject that is based on 2013 Curriculum has significant difference compared to the previous physical education subject. This is due to the fact that integrated physical education has its own uniqueness in terms of planning, systematic implementation, and instructional medium. This research aims at producing guidance in implementing character values integrated in physical education in elementary school. The method used in this research is research and development (R\&D) method, which includes preliminary research, model designing, limited trial, and extensive trial, as well as validation and dissemination. The findings of the research show that character values can be implemented in physical education in elementary schools in Sumedang Regency.
\end{abstract}

Keywords: Character Values Implementation, Integrated Physical Education, and Character Building.

\section{Introduction}

One of the causes of problems in the educational field is the lack of education that can develop intrinsic values of humanity, since "intellectual education" and "education of values" are considered separated. This dichotomy shows the weakness in planning because moral values are not in a different dimension with intellectual values; in fact, it is the foundation of the intellectual development. As stated by Sapriya, [1] this kind of program planning is the main source of moral and character crisis among students, graduates, teachers, even education management. It is undeniable that there is a degradation of national identity values in our younger generation, which is caused by the lack of character education. Whereas, education character is the transformation vehicle of culture, value, science and technology, art and character education, which has been the center of the development of national character in both formal and informal education.

\footnotetext{
*Corresponding author: ayisuherman1960@gmail.com
} 
Based on the writer's observation, nowadays, character education is generally executed only in classrooms. This somehow burdens the students to develop, since what they actually need are freedom to move and higher thinking skills, which need to be actualized without pressure. It is believed that character education implementation done in schools will be more effective if it is integrated with various subjects, not excluded into one single subject.

To overcome the problems of character education, a learning strategy is needed in building the students' character, since it has to be positioned as an effort to develop a strong character. Thus, every education unit has to have their own character building programs integrated with all intracurricular and extracurricular activities.

According to Lickona [2], character education is a potent medium to motivate democratic living, which becomes the reflection of human character grown in each individual in the context of collective living. In a democratic society, every person has a moral commitment in terms of living together, such as respecting their own rights and the rights of others, following the norms and rules, participating in togetherness, believing in the benefits of living together, and so on.

In relation to the aforementioned issue, one of the teachers' strategies to implement character education to the students is through physical education that is integrated with various activities in other subjects. The best implementation of character education for the students will have an impact on the expected development of national character values.

This research has developed nine character values from 18 characters developed in the elementary schools, namely creativity, independence, democracy, appreciation of achievement, friendship/communication, peace, reading interest, social care, and responsibility. This character implementation will be carried out in elementary school.

According to Depdiknas [3], character can be interpreted as a good individual quality, meaning that an individual knows virtues, has willingness to do good deeds, and is well behaved, as the result of intellectual development (olah pikir), spiritual and emotional development (olah hati), physical development (olah raga), affective and creativity development (olah rasa dan karsa). Thus, research on the implementation of character values in fun physical education in elementary school can be one of the efforts to build national character.

Albertus [4] provides examples on the characters classification. Character values implemented to the students cannot proceed if they are not maintained properly. In order to build a more effective character education, there are three basic approaches that need to be embedded, namely school-based education (class), school culture, and community. In-class character education is integrated with the curriculum that consists of kinds of quality the teachers need to possess, so a special subject for character education is not needed.

To reach the objective, a whole and thorough character education is mandatory. According to Lickona[2], character education is a potent medium to motivate democratic living, which is the reflection of human character grown in each individual in the context of collective living.

Linda [5] explains that those values are "values of being" and "values of giving". Values of being are values embedded within the self that develop into actions and how we treat others, for example: being honest, kind, peaceful, dependable, discipline, and in the limit. Values of giving are values that need to be practiced or given; with consideration that what will be received is equal to what will be given, for example: fidelity, trust, respect, love, affection, sensitivity, unselfishness, virtues, friendliness, justice, and generosity.

Nurgiyantoro [6] defines physical education at school as a part of thorough education that includes character education, which strives to implement good behavior so that children will be able to understand (cognitive), feel and make choices (affective), and implement them to their behavior on a daily basis (psychomotor). Similarly, Suryanto [7] believes that through the implementation of character education, children will be more 
sensitive and reflective to the sense of humanity, to themselves, to their surroundings, to others, and to God.

\section{Methods}

This research refers to the research and development procedure as explained by Borg and Gall [8]. The systematic steps of research and development in implementing character education values in the physical education subject in elementary school are:

1. Doing an preliminary research, which means gathering information that includes literary review regarding the effort of implementing character values integrated in physical education subject;

2. Composing the first draft of the implementation of character values integrated in physical education subject;

3. Conducting trials that include limited and extensive trials focusing on the implementation of values integrated in physical education subject; and

4. Conducting validation and dissemination tests.

The subjects of this research were all elementary schools in Sumedang Regency. To determine which school would be the sample of this research, cluster sampling technique was employed. Based on the sampling, there are seven elementary schools in 26 districts in Sumedang Regency appointed as samples that represent each district.

The data collection was conducted using the following instruments: observation, interview, questionnaire, and test. Based on the data collection technique, qualitative and quantitative data were gathered. Qualitative data were analyzed using descriptive analysis technique, which employed sustainably based on the achieved data by Maleong [9]. As for quantitative data, the data were analyzed by using statistical analysis approach, or T-test analysis technique, in which the data processing used SPSS version 21 software on a computer.

\section{Result and Discussion}

The result of introductory research finds out that a majority of teachers are not used to implement character values integrated in physical education subject. In fact, several previous research reveal that form of learning model of Curriculum 2013 has not been implemented yet. This is caused by three factors: First, elementary school teachers have not received training on the implementation of character values integrated in physical education subject. Second, 2013 Curriculum will be implemented in 2016/2017 Academic Year, so that the implementation of character values is still scattered or not yet integrated. Third, the teacher forum has not been able to develop characters in physical education for elementary schools students, since the numbers of qualified trainer are still limited.

The planning stage of designing the implementation of character values integrated in physical education subject in elementary school consists of the following syntaxes. First analyzing students' needs based on the implementation of character values. Second, adding activities filled with character values to several learning activities in an integrated manner. Third, evaluating character-based learning that will be added or reduced based on the students' needs.

The results of implementing character values in integrated physical education subject can be drawn from a limited test conducted at SDN Panyingkiran III in Sumedang Regency. The instrument used in this research was a questionnaire consisting 10 questions, which are related to character values programmed in 2013 Curriculum such as independence, discipline, responsibility, honesty, cooperation, spirituality, communication, mutual care, creativity, and peacefulness. There are 10 questions used as the data collecting instrument, which have five alternative answers: never (1) rarely (2) sometimes (3) often (4) very often (5) regularly. 
Based on the above respondents' distribution answers, it can be identified that there were 34 students who are observed by one physical education teacher. From the limited test, ten character behaviors can be seen in the questionnaire's average result on this following table.

Table 1: The Result of Students' Character Questionnaire

\begin{tabular}{|l|c|c|c|c|c|c|c|c|c|c|}
\hline $\begin{array}{l}\text { Number } \\
\text { of } \\
\text { question }\end{array}$ & 1 & 2 & 3 & 4 & 5 & 6 & 7 & 8 & 9 & 10 \\
\hline Frequency & 66 & 65 & 64 & 66 & 62 & 62 & 68 & 66 & 66 & 59 \\
\hline $\begin{array}{l}\text { Percentag } \\
\text { e }\end{array}$ & $\begin{array}{c}94.2 \\
9\end{array}$ & $\begin{array}{c}92.8 \\
6\end{array}$ & $\begin{array}{c}91.4 \\
3\end{array}$ & $\begin{array}{c}94.2 \\
9\end{array}$ & $\begin{array}{c}88.5 \\
7\end{array}$ & $\begin{array}{c}88.5 \\
7\end{array}$ & $\begin{array}{c}97.1 \\
4\end{array}$ & $\begin{array}{c}94.2 \\
9\end{array}$ & $\begin{array}{c}94.2 \\
9\end{array}$ & $\begin{array}{c}84.2 \\
9\end{array}$ \\
\hline
\end{tabular}

The table above shows that the average percentage of the questionnaire result was $92 \%$ which can be categorized as excellent. The highest percentage of the questionnaire average result was derived from the question number 7 that is about the students' communication skill, and the percentage result was $97.14 \%$. Meanwhile, the lowest percentage was derived from the question numbers 5 and 6 that is regarding the cooperation skill and sincere praying, and the percentage as $88.57 \%$. Furthermore, it can be concluded that character values have been integrated in the subjects, but there is still a gap between subjects and character values.

Based on the aforementioned data, it can be identified that the character values integrated in physical education can be implemented for students in elementary schools in Sumedang Regency. In line with character education model, Kesuma [10] explains that the main principles of implementing character values integrated in physical education subject that need to be put forward are: (1) the foundation of teacher-student interaction in the learning process is affection, (2) teachers' attitude and behavior has to reflect the believed values, (3) teachers see their students as developing subjects in which their development is related to the teachers' role. Hereinafter, coaching and implementation of this character model can be done through designing a lesson plan (Rencana Pelaksanaan Pembelajaran (RPP), exploring, elaborating, and confirming the meaning of the materials discussed as well as evaluating the observation which will be reported to the school community for further follow-ups Masitoh [11].

The implementation of character values integrated in physical education subject in elementary school is beneficial for the students to reduce the teachers' domination, which oftentimes imposes their desire in teaching academic-oriented subjects while disregarding psychological aspects that are considered as intrinsic needs of elementary school students. One of the fundamental problems in the educational process in elementary school is that there are some faults done by teachers in treating their students in the learning activity by Agustin[12]. With curriculum implementation training program conducted by Departement of Education for teachers, especially the teachers in elementary schools in Sumedang Regency, it is expected to boost the teachers' encouragement in seeing the importance of learning essence is in elementary school.

The results of the research show that there is a difference in the subjects' implementation in the area of city center, districts, and rural areas. This is quite reasonable because there are variations and demands in each region, especially the presence of teachers. This statement is supported by the research conducted by Haenilah [13] which says that, "teachers as educators whose sole responsibility is to teach, has personality characteristics which are influential to the success of human resources' development". Teachers' personality is an important factor in determining the level of success of the 
students' learning process. The above research result is in accordance with Syah [14] who asserts that the aforementioned personality will be the one that determines whether a teacher will be a good educator and coach for their students or the one who destroy their future, especially elementary school students and those who are still in pursuit of their sense of identity.

The result of the data analysis shows that the actualization of the implementation of character values in integrated physical education subject varies at each elementary school. However, they all give significant influence towards the elementary school students' personal skills. This statement is supported by the result of a research conducted by Haryani [15] which says that children who have a lower level of quality character will shows low social emotional, so that the children might experience some difficulties in learning, having social interaction, and controlling themselves.

Based on the school's policy in implementing character education, Lickona [2] accurately says that the strategies of the implementation of character education at school has to take an integrated path. First, integrating character education content formulated into all subjects. Second, integrating character education into daily school activities. Third, integrating the haracter education into structured or planned activities. Fourth, building communication and cooperation between schools and parents.

The implementation of character education in elementary school refers to tens character quality pillars by Megawangi [16], they are: love to God and His creations, responsibility, discipline and independence, being honest, trustworthy, and wise, respect and hospitality, mutual cooperation and confidence, creativity and hard work, leadership and justice, being kind, humble, and tolerant, as well as peace and unity. Character education is in line with students' behaviors, particularly their personal skills and the students generally will have positive behavior as the result of studying the characters. According to Surya [17], the characteristic features of behaviors based on the result of studying is intentional, positive, and effective. The change of behavior is intentional, meaning that experience or practice is intentionally and consciously done and it does not happen accidentally. The change of behavior is effective, meaning that the change of behavior remain relative and if it is needed, it can be reproduced and used, like in problem solving, tests, or daily lives in order to sustain its survival.

\section{Conclusions}

The result of the research on the implementation of character values integrated in physical education subject in elementary school students shows that: First, seen from the teachers as curriculum developers aspect, character education that is currently implemented has only been executed in the forms of direction and advice, and has not yet integrated in the learning scheme. Most teachers are still confused to conduct character education due to the fact that the implementation of 2013 Curriculum that consists of character education will only be enacted in 2016/2017 Academic Year. Second, the students are not used to the character education presented in a learning model, as it is usually, showcased by the teachers. Third, the effectivity of implementing character values into integrated physical education. It can be concluded that character education for elementary school students does not only come in the form of characters that are programmed in the lesson plans. However, the teachers must begin it with good examples done both in the classroom and daily lives.

\section{References}

1. Sapriya. "Perspektif Pemikiran Pakar tentang Pendidikan Kwarganegaraan dalam Pembangunan Bangsa (sebuah Kajian Konseptual Filosofis Pendidikan Kewarganegaraan dalam Konsteks Pendidikan IPS”. Disertasi tidak Dipublikasikan, PPS UPI Bandung.(2007). 
2. Lickona, Tom. Eleven Principles of Effective Character Education.Journal of moral Education. 25:93-100. (1996).

3. Depdiknas. Grand Design Program Pendidikan Anak Usia Dini Nonformal Tahun 2007-2015. Jakarta: Direktorat PAUD Dirjen PLS. (2010)

4. Albertus, D.K. Mengembangkan Kultur Akademis Bagi Pembentukan Karakter. Makalah disampaikan dalam Konfrensi Nasional dan Workshop Asosiasi Psikologi Pendidikan Indonesia. Peran Pendidikan dalam Pembangunan Karakter Bangsa. Malang: Program Studi Psikologi UM. (2010)

5. Linda. N. Eyre. Teaching Your Children Values. New York: Simon and Chuster. (1995)

6. Nurgiyantoro, Burhan. "Implementasi Pendidikan Karakter dalam Bahan Ajar". Makalah Disajikan dalam Stadium Generale di Jurusan FBS FKIP Universitas Sebelas Maret. Surakarta. 27 Nopember 2011. (2011)

7. Suryanto, Edi. Pendidikan Budi Pekerti Berbasis Cerita Anak Melalui Penanaman Nilai Etis Spritual di SD. Jurnal Sekolah Dasar. No. 1: (2015).

8. Borg, Wolter R., Gall Meredith Damien. Educational Research an Introduction (Third Edition). New York. Longman Inc. (2003).

9. Maleong, Lexy J. Metodologi Penelitian Kualitatif. Bandung.Remaja Rosdakarya. (2006)

10. Kesuma, D dan Salimi, M. Kajian Teori dan Implementasi Pendidikan Karakter di Sekolah (Sebuah Pengalaman Pusat Pengkajian Pedagogik). Prosiding Seminar Internasional Prodi Pendas SPS UPI Bandung. (2012)

11. Masitoh, dkk. Strategi Pembelajaran di Taman Kanak-Kanak. Jakarta: Universitas Terbuka. (2005)

12. Agustin, M. Deteksi Dini dan Stimulasi Kecerdasan Jamak Anak Usia Taman KanakKanak. Prosiding Seminar Internasional Penguatan Pendidikan Karakter Pada Jenjang Pendidikan Dasar di Era Global. Prodi Pendas SPS UPI. (2012)

13. Haenilah, E. Analisis Kebutuhan Profesionalisme Guru Sekolah Dasar Pasca Sertifikasi. Jurnal Sekolah Dasar. No.2: 99-198. (2015).

14. Syah, Muhibin. Psikologi Pendidikan dengan Pendekatan Baru. Bandung: PT. Remaja Rosdakarya. (2000)

15. Haryani. Pendidikan Karakter Melalui Bimbingan dan Konseling Bagi Siswa Sekolah Dasar. Prosiding Seminar Internasional PenguatanPendidikan Karakter Pada Jenjang Pendidikan Dasar di Era Global. Prodi Pendas SPS UPI. (2012).

16. Megawangi. Pendidikan karakter; Solusi yang Tepat untuk Membangun Bangsa, Depok: Indonesia Heritage Foundation. (2003).

17. Surya, Muhammad. Psikologi Pembelajaran dan Pengajaran. Bandung Yayasan Bhakti Winaya. (2000). 